\title{
Predictors of Seasonal Flood Control in Owode Yewa, Ogun State, Nigeria
}

\section{Ojo Oladimeji Olusola ${ }^{1 \times}$ Adejugbagbe John Adewale ${ }^{2}$}

'Urban and Regional Planning Department, Federal Polytechnic Ilaro, Ogun State, Nigeria. Email:oladimejio5@gmail.comTel:+2348063409884

-Architecture Department, Federal Polytechnic Ilaro, Ogun State, Nigeria.

Email:waleadejugbagbe@gmail.comTel:+2348033585198

\section{Abstract}

The increasing challenges of seasonal flood pose serious threat to lives and properties of citizens. This is a major concern for residents in an uncontrolled environment like Owode town in Ogun State. The current study examined a linkage between land use planning and flood control in Owode town. Utilizing a systematic sampling technique, a structured questionnaire was administered to 191 household heads in the study area. The data was analysed with logit Regression model and Marginal Effects at $5 \%$ level of significance. The result points out the significance of good road network (Beta $=0.056 ; \mathrm{p}=0.008)$ better drainage system $($ Beta $=0.024 ; \mathrm{p}$ $=0.000)$, planned environment $($ Beta $=0.023 ; \mathrm{p}=0.000)$, and public awareness $($ Beta $=0.016 ; \mathrm{p}=$ 0.011 ) as land use planning measures to completely stop flood occurrences in Owode town. Thus, an integration of these measures can sustainably reduce flood risk in flood prone towns like Owode. The study therefore recommends the need for government to re-evaluate its environmental policies to control both human activities and natural habitats.

Keywords: Land use, Flood, Planning, Predictors, Seasonal and land use.

Citation | Ojo Oladimeji Olusola; Adejugbagbe John Adewale (2020). Predictors of Seasonal Flood Control in Owode Yewa, Ogun State, Nigeria. Asian Review of Environmental and Earth Sciences, $7(1): 1-8$.

History:

Received: 10 September 2019

Revised: 14 October 2019

Accepted: 17 December 2019

Published: 8 January 2020

Licensed: This work is licensed under a Creative Commons

Attribution 3.0 License (c)

Publisher: Asian Online Journal Publishing Group
Acknowledgement: Both authors contributed to the conception and design of the study.

Funding: This study received no specific financial support.

Competing Interests: The authors declare that they have no conflict of interests.

Transparency: The authors confirm that the manuscript is an honest, accurate, and transparent account of the study was reported; that no vital features of the study have been omitted; and that any discrepancies from the study as planned have been explained.

study as planned have been explained.
Ethical: This study follows all ethical practices during writing.

\section{Contents}

1. Introduction

2. Literature Review and Conceptual Framework

3. Theoretical Framework of the Study.

4. Conclusion and Recommendations

References.. 


\section{Contribution of this paper to the literature:}

This study serves as a guiding instrument on how to provide the necessary facilities lacking in the study area in order to mitigate seasonal flooding in the study area.

\section{Introduction}

Human activities demand a place to be accomplished and there is limit to existing land. Shortage of suitable space for development encourages building or construction on unauthorized land which include reserved land. Land use planning is not based on land classification alone but the comprehensive decision on the interrelationship of different activities [1]. Land use planning refers to the process by which land is allocated between competing and sometimes conflicting uses in order to secure the rational and orderly development of land in an environmentally sound manner to ensure the creation of sustainable human settlements' [2]. Planning for land use is a proactive approach in maintaining sustainable neighbourhood characteristics. Land use planning acts as an agent in the prevention of land use conflicts. The decisions on land use location relate to the socio-economic consideration rather than physical characteristics and neighbourhood quality.

The influence of human being on earth cannot be over emphasized. Human settlement is changing regularly due to daily activities and urban planning need to observe urbanization as a tool for development rather than a problem [3]. Therefore, it requires sustainable strategy to address urban issues including flooding that causes environmental deterioration. Flood have negative impact on physical environment and socio- economic activities [4]. The seasonal flooding experienced in the study area keeps on increasing with destruction of available roads and valuable properties. Therefore, the study aimed to examine land use planning as an instrumental tool for flood reduction and management in Owode area of Ogun State in order to provide sustainable solutions to seasonal flooding in the area. The objectives are to examine the physical patterns of the areas, level of compliance of physical structures with existing regulations, and availability of flood control and management infrastructure in the study area.

\section{Literature Review and Conceptual Framework}

The literature review covered causes of flooding, land use planning and integrate non-structural model, flooding as a natural hazard need to be examined with various means. Land use planning as a tool for positioning structure according to uses allow neighbourhood to know areas with ecological problems.

\subsection{Causes of flood in Neighbourhoods}

There are various causes of flooding in an area. Ajibola, et al. [5] posited that areas with engineering drainage construction, settlement with a high concentration of housing and population are liable to climate change which is one of the causes of floods. Spaliviero, et al. [6] identified topography and landforms in Limpopo river basin as main causes of the flood in the region. Adetunji and Oyeleye [7] investigated causes and effects of floods in Apete, Ibadan. Their findings show that poor waste management and construction along water channels contributed to the floods. Lamond, et al. [8] studied the role of solid waste management in urban area as found that, population increase and inefficient management of waste in urban areas result to flooding.

Unplanned settlement and slopes contribute to floods [9]. Haphazard construction of homes has blocked several natural water ways lead to frequent floods throughout the rainy seasons notably within the months of March, April and May of each year [10]. Human activities have been the contributor to the level of floods [11]. Therefore, adequate land use is required for sustainable physical planning. Katchova [12] Identified causes of flood in Anambra state to include unplanned environments, poor drainage systems, high population, nonchalant attitude of government and changes in climate. Ali and Sulaiman [10] concluded that, due to the non-existence of drainage systems, storm water creates huge puddles that become breeding places for mosquitoes that causes malaria in Informal Settlements of Zanzibar.

Kwari, et al. [13] opined that weakness in environmental impact assessment (EIA) report maps in flood prone areas and attitude of both inhabitants and government in response to flood risk increases the occurrence.

\subsection{Effects of Flooding}

The effects of floods on the economy of an area manifest on a decline on the farming productivity that can lead to poverty Pauw and Thurlow [14]. Ebuzoeme [15] examined the effect of flood on six communities in Awka and found the effect of flooding on them to include building damage, road congestion, and deterioration of the environment, high poverty level and negative impact on wellbeing of inhabitants. In Zimbabwe, 246 persons were killed. Road, crops and livestock were destroyed by flooding Gharagozlou, et al. [16]. Etuonovbe [17] examined the devastating effects of flood on the border between Ogun and Lagos States and Northern part of the country. The study concluded that there must be synergy between the actors in built environment in order to mitigate the consequences of flooding in the study area.

The consequences of flooding manifested in both social and economic activities of inhabitants [18] and Kwari. The damage posed by flood in Pakistan affect mostly mud buildings due to the weak foundation and unprocessed material [19]. Economically it is very hard to quantify the damage of flooding [20]. The social impact is attributed to the trauma experienced as a result of the incidents and aftermath. Dewan [21] concluded that traditional knowledge and indigenous practices should be included to reduce socio-economic impact.

\subsection{Land Use Planning}

Proactive measures to scale back the threat of disaster have to be compelled to be an integral facet of urban planning [22]. Local Town Planning Authorities and local governments have various planning tools to control and preserve a settlement from disasters. The land use planning is to ensure desirable standard in use of land to prevent or minimize flooding. Land use planning is the coordination of different land uses, commercial, residential, public use, circulation, agricultural uses in a settlement. Recently, consideration for land use in an urban centre is based on economic values rather than environment consideration. The demand for commercial and 
social space raise concerns on the impact on changes in the existing land use. Inadequate knowledge in the implementation and content of comprehensive land use plan is a short fall in physical planning [23]. Flood control and management are crucial issue that needs the cooperation of their scientist in relevant fields [24].

Abolade, et al. [25] concluded that road improvement, and availability of fund and equipment are germane to flood control in both rural and urban areas. Hula and Udoh [26] identified engineering and sufficient drainage system as a basic requirement for effective discharge of flood water. The sustainable solution to flood risk is to integrate existing population into flood management team to improve required data and land enlighten the public $[27]$.

Flood control is very difficult in low land areas with dense population, adequate zoning techniques is very important [28]. The authors further described flood situation in Brazil as noncompliance with master plan of cities that led to unplanned environment. The provision of land use map in flood prone areas provides a decent example of risk reduction issues into mainstream urban planning [29]. The demand for food, water and energy will increase pressure on existing land use and environmental pollution [30]. Reasons for an absence of enforcement might be corruption, lack of political will for enactment or a weak legislature. But for most of the growing variety of urban poor who, by definition, live illicitly, building rules and regulations could be a nonissue [29].

Moreover, Luo, et al. [31] reviewed flood disaster in China and Japan, findings indicate that multi-purpose flood management policies in both countries were similar and construction of dams for flood control and public awareness in risk of flooding. Adelekan [32]; Tang, et al. [33] concluded that there is a need for upgrading and new management strategies in the meteorological forecast and proper analysis of flood warnings and public awareness. Nchito [34] opined that consideration of the local situation in flood policy can influence or improve both national and regional objectives in improving situations. The crucial issue to be self-addressed is that the extent to which government would formulate development policies which will have a precise impact on trends of urban growth Ali and Sulaiman [10]. Correia, et al. [35] studied flood risks in unplanned settlements in Lusaka and the findings revealed that occupants mostly were not aware of the danger awaiting them due to the low price of land.

Globalization and urbanization increase human activities. Demand for land for other uses increases the pressure on available land. The land is fixed in nature but population keeps on increasing. Therefore, the alteration on the existing land encourages environmental degradation and flood risk. Land use planning serves as an important tool in flood reduction, it involves adequate separation of uses.

\section{Theoretical Framework of the Study}

This study is underpinned by integrated non-Structural Model (ISM), a component of Flood Risk Management Model (FRM). The model which was developed by Idris and Dharmasiri [36] stresses the magnitude of land use planning, flood warning systems, evacuation, preparedness and insurance as options available at the individual, institutional and government level for flood control. It has been recognized as an alternative to traditional structural model. According to Smith and Bugni [37] structural flood control alone cannot solve the flood risk and hazard problems because flood control measures have been usually planned in isolation from other development. Hence, unlike non-structural model, structural flood model is perceived as reactive rather than proactive.

The proponents like [38] debated that flood control measures should be integrated and aligned with nonstructural methods, like land use planning to produce a more comprehensive flood management. In the main, the focus will shift from post-disaster response and relief centric approach to pre-disaster proactive preparedness and mitigation centric approach focusing on disasters as direct concern and a common understanding of the concept of vulnerability as important for developing a central notion [37]. Thus, adapted land use and spatial planning in flood-prone areas guarantees achievement of most efficient and sustainable reduction of flood risks. This will reduce potential damage (vulnerability) by flood in these areas.

The conceptual framework for the study in Figure 1 describes relationship between all variables that contribute to the challenges faced in areas experiencing flooding, it was derived from literature reviewed. Heavy rainfall and climate change serves as a major factor, recently, climate change determines situation because it comes with changes in weather condition and due to increase in modern technology and economic activities, there is expansion of land for industrial activities that prompt population increase globally. Therefore, these activities have negative impact on the atmosphere and land degradation, and pollution that affect every ramification of human existence. Also, land use conversion from the original use mostly does not comply with existing regulations.

Presently in Owode town, there is an increase in commercial activities and physical expansion. People are moving from parts of the state and neighbouring country like the Republic of Benin to Badagry and Lagos through Sango Ota and other parts of Ogun State. The attributes of the town encourage the influx of people with demand for housing and other activities for sustainability. These contribute to unplanned environments usually evident in border towns.

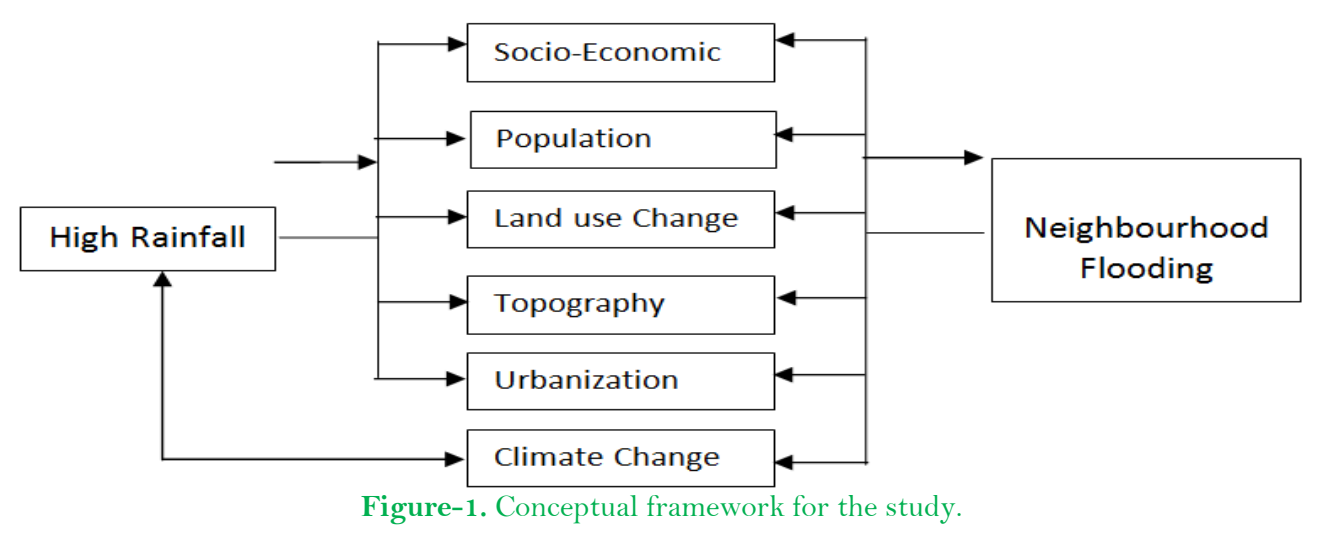




\subsection{Research Method}

Following Integrated Non-Structural Flood Risk Management Model, a Logit model of binary regression was developed. The choice of the model is informed by the nature of the indicator variable and largely by the data involved.

Mathematically, the model may be written as;

Flood Control $=\mathrm{f}$ (Land use Planning)

$$
F L C=f(L A P)
$$

where;

FLC = Flood Control; and LAP = Land use Planning

LAP is measured by; RON = Road Network; DRA = Drainage System; PLA = Planned Environment; LAM $=$ Land use

Map; and PUB = Public Awareness

In other words, Equation 1 becomes;

$$
F L C=f(R O N+D R A+P L A+L A M+P U B)
$$

By calibrating Equation 2 into logit model, the study arrived at;

where; $X_{i}=$ vector of explanatory variables

$$
\operatorname{Pr}\left(\text { Flood Control }=1 \mid X_{i}\right)=f\left(X_{i}^{\prime} \beta_{i}^{\prime}\right)
$$

$\beta_{i}=$ vector of coefficients of $X i$

Therefore, Equation 3 transforms into;

$$
\ln \left(\frac{F L C}{1-F L C}\right)=\bar{\alpha}+\beta i\left(X_{i}\right)+\varepsilon \quad \text { (Cameron and Trivedi, 2009) (4) }
$$

where; $\ln =\log ; \bar{\alpha}=$ intercept; $\mathcal{E}=$ disturbance term

By expansion, we have;

$$
\ln \left(\frac{F L C}{1-F L C}\right)=\bar{\alpha}+\beta_{1} R O N+\beta_{2} D R A+\beta_{3} P L A+\beta_{4} L A M+\beta_{5} P U B+\varepsilon
$$

The computation of marginal effects is expedient because the coefficients of (5) do not lend itself to a simple interpretation $[22,24]$.

$$
\frac{\partial p}{\partial(X j)}=\wedge\left(X^{\prime} \beta\right)\left[1-\wedge\left(X^{\prime} \beta\right\rceil \beta j=\frac{e^{X^{\prime} \beta}}{\left(1+e^{X^{\prime} \beta}\right)^{2}} \beta j \quad\right. \text { (Katchova, 2013; 29:3) }
$$

Where; $\frac{\partial p}{\partial(X j)}=$ marginal effects of predictors; $\wedge=$ cumulative difference function; $\beta j=$ beta coefficients of predictors; and $e=$ exponential.

A priori expectation is expressed as $\beta_{1}-\beta_{5}>0$. This implies that the study expects positive relationship between dependent variable and the predictors. Lastly, all analyses are conducted at $5 \%$ level of significance.

Owode Yewa is a town situated in Yewa South Local Government of Ogun State, Nigeria. From the findings of the study, the town is dominated by artisans and traders as economic actors. One of the reasons for this concentration is closeness of the town to neighbouring international border towns. However, no information is specifically available on the total population of the residents in this town. Even information on population census by National Population Commission [39] is only available at local government level. In spite of this, the researcher ensured that the current research duly followed scientific processes in arriving at a representative sample. A basic assumption of this paper is that the experience on flood occurrence in the study area can only be provided by those who have stayed long in the town. Thus, only household heads were considered as the respondents in the study area. To get a working figure of household heads in the study area, the researcher visited each community and had joint consultation with the Community Development Associations (CDAs) during which residents were familiarised with the objectives of the study and solicit for their cooperation. Only CDAs registered by Yewa South Local government in Owode Yewa Township were considered in the study. A total of 18 such CDAs were identified and visited. At each of the consultation exercise, the total number of household heads in each of the community was obtained from the chairmen of the associations. This was made possible through the membership register maintained by each CDA. A total number of 380 household heads were obtained through the process, and formed the sample frame of the study as the household heads were the unit of analysis for the study.

A sample size of 191 was determined through the application of sample size determination formula recommended by Garson [40] for a known population. The procedure was observed via the formula below;

$$
\mathrm{S}=\frac{X^{2} N P(1-P)}{d^{2}(N-1)+X^{2} P(1-P)} \quad \text { Krejcie and Morgan [38] }
$$

Where $\mathrm{s}=$ sample size; $X^{2}=$ table value of chi-square at 1 degree of freedom for desired confidence level (0.95); $\mathrm{N}=$ population size (320); and $\mathrm{P}=$ population proportion (0.5). Furthermore, in order to create representative probability-based selection, the study employed systematic sampling procedure to select every $5^{\text {th }}$ household approached in each of the communities visited. A total number of 178 copies of the questionnaires representing a retrieval rate of $93 \%$ were retrieved. From the 178 copies of the questionnaire collected, 12 had missing response items which made them unusable. The remaining 166 (87\%) questionnaires were used in the analysis. This response rate is considered highly sufficient considering that it is close to three times the acceptable standard for survey response rate of $30 \%$ as suggested by Luo, et al. [31].

\subsection{Presentation, Analysis and Discussion of Findings}

The information in Table 1 reveals the response of the respondents (household heads) to a question on whether there is poor or good flood control in the study area. The majority of the respondents which constituted more than $60 \%$ of the respondent considered flood control in the study area as poor while almost $36 \%$ rated it to be good. The remaining percentage of the respondents provided no answer to the question. The implication of this finding is that there is poor flood control in Owode area of Ogun State. Subject to empirical investigation, the following Figure 2 and Figure 3 further support the descriptive finding. Figure 2 shows the major road in Owode without adequate drainage system. This situation results frequently in flooding in the area. Figure 3 shows the existing blocked and damaged drainage system contributing to inability to control flood, the majority of access roads within the town 
were not tarred and lack drainage systems. Thus when it rains, rain water cannot be efficiently evacuated thus resulting in flooding in the area.

Table-1. Flood control distribution frequency.

\begin{tabular}{c|c|c|c} 
Flood & \multicolumn{3}{l}{} \\
\hline Control & Frequency & Percent & Cum. \\
\hline Poor & 100 & 60.24 & 60.24 \\
\hline Good & 59 & 35.54 & 95.78 \\
\hline Missing & 7 & 4.22 & 100.00 \\
\hline Total & 166 & 100.00 & \\
\hline
\end{tabular}

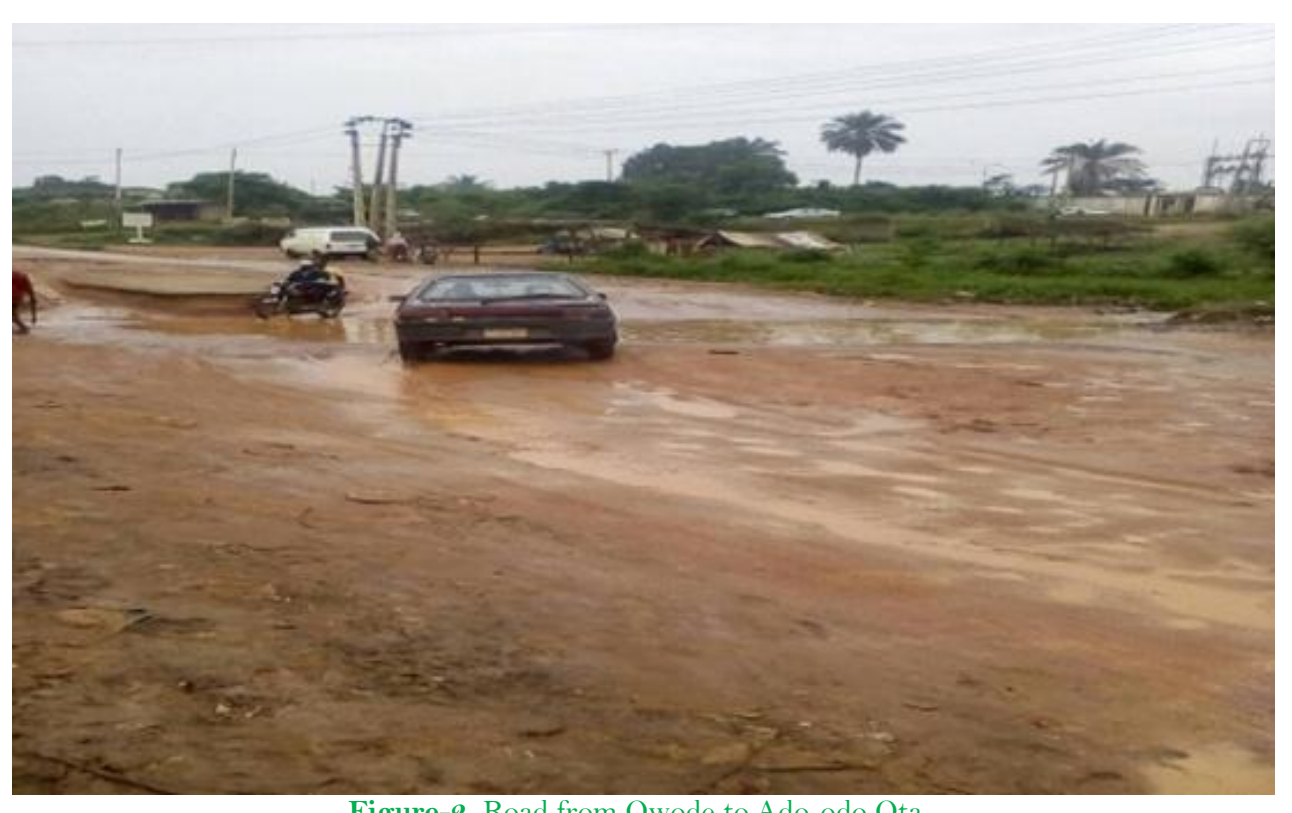

Figure-2. Road from Owode to Ado-odo Ota.

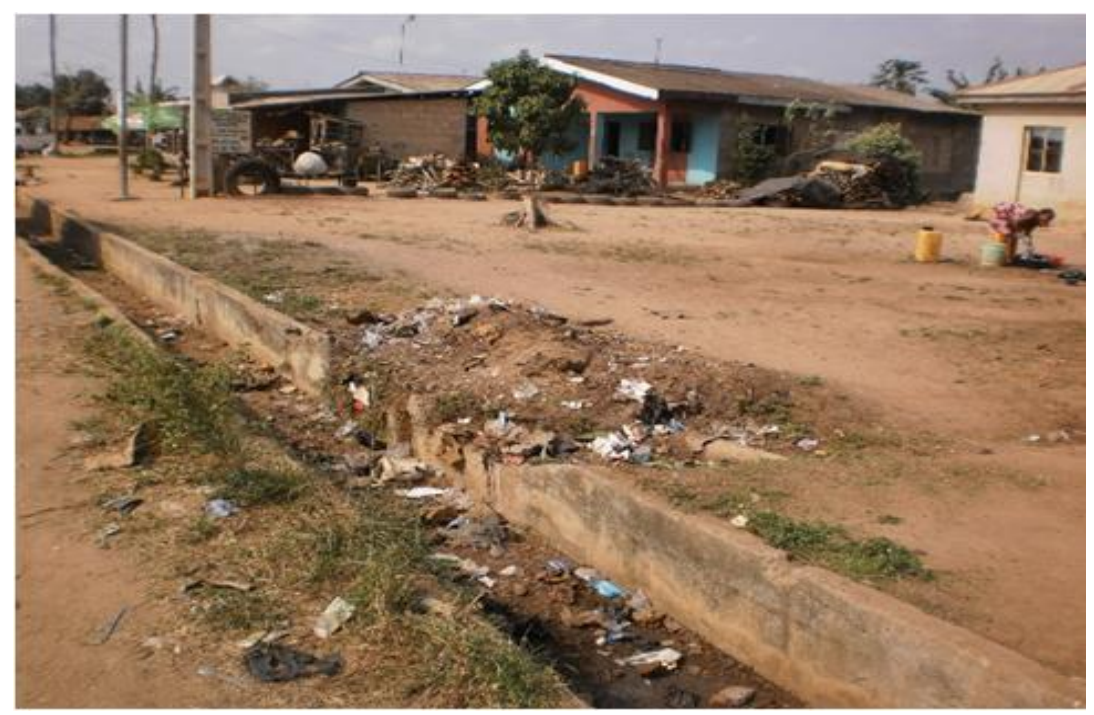

Figure-3. Damage drainage system.

The Table 2 reports major findings of the study. The likelihood ratio (0.0014) as revealed in the table indicates that all the slope coefficients of the study model are not simultaneously equal to zero. All the model predictors' coefficients are greater than zero thus, ensuring that the model adequately fits the study data. These further exhibits appropriateness of the study logit regression model. Moreover, all predictors except land map variable are in addition statistically significant. This information is revealed in Table 2 and Table 3.

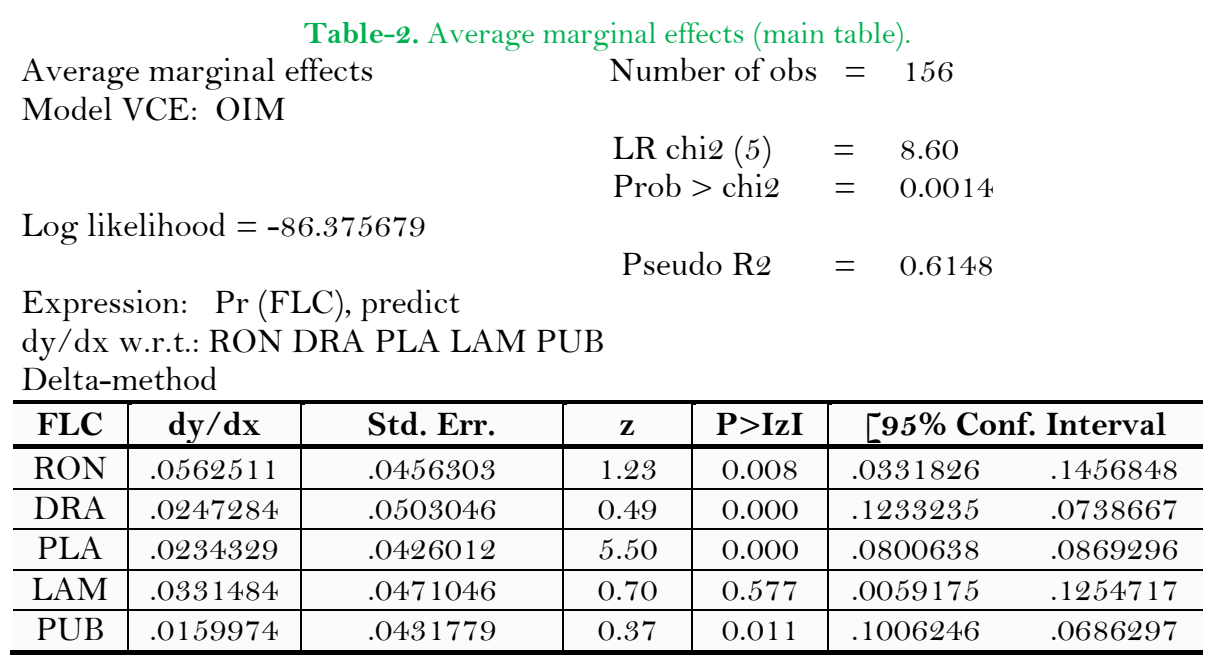




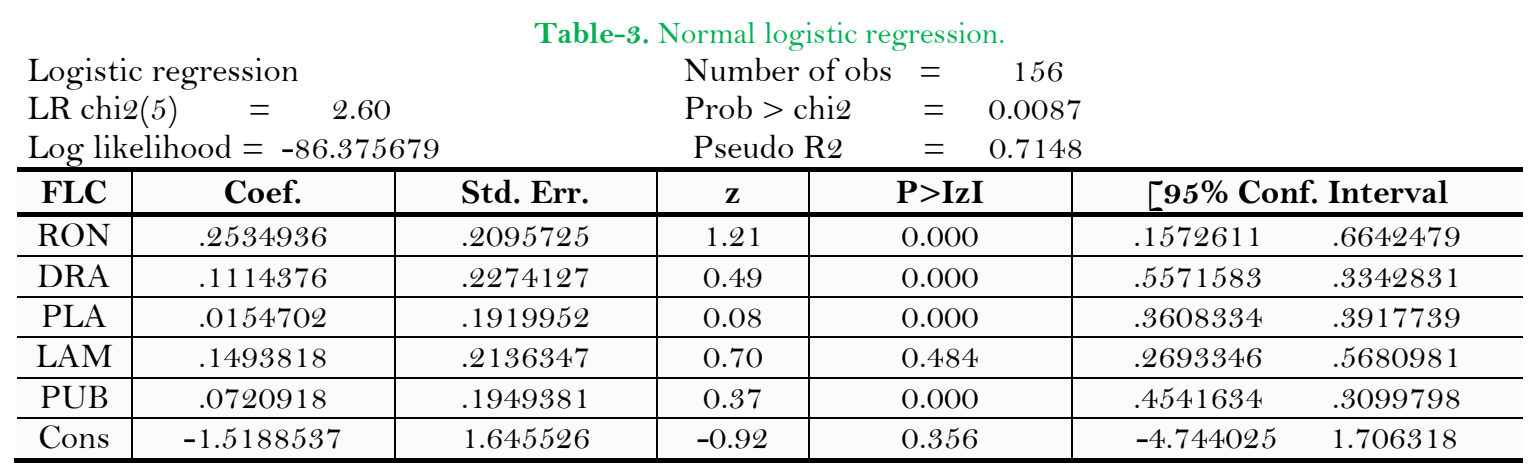

The implication is that with an improvement in road network, drainage system, planned environment and public awareness about flood prevention flood control in Owode area is likely to significantly improve. Logistic regression does not make assumptions concerning the distribution of scores for the predictor variables. However, it is sensitive to multicollinearity [41]. The study conducted Spearman's Correlation statistics for all the predictors used in formulated models. The Table 4 shows that there is weak multicollinearity among the regressors.

\begin{tabular}{c|c|c|c|c|c}
\multicolumn{7}{c}{ Table-4. Spearman's correlation. } \\
\hline FLC & RON & DRA & PLA & LAM & PUB \\
\hline RON & 1.0000 & & & & \\
\hline DRA & 0.0236 & 1.0000 & & & \\
\hline PLA & 0.0426 & -0.0037 & 1.0000 & & \\
\hline LAM & 0.1121 & 0.1022 & -0.0698 & 1.0000 & \\
\hline PUB & -0.0420 & 0.1217 & -0.2897 & 0.0126 & 1.0000 \\
\hline
\end{tabular}

Moreover, the study could correctly predict that there is $64.7 \%$ likelihood that the residents in Owode area perceived flood control in the area to be poor. This is revealed by information in Table 5. Also, the Average Marginal Effects analysis shows that with an increase in the response categories of road network from lowest to highest the probability of good flood control significantly increases by $5.6 \%$. Increase in the response categories of drainage system from lowest to highest scale significantly increases the probability of good flood control by $2.4 \%$. With an increase in the response categories of planned environment from lowest to highest scale the probability of good flood control is significantly increased by $2.3 \%$; and an increase in the response categories of public awareness from lowest to highest scale increases the probability of good flood control by $1.5 \%$. However, land map was found to be an insignificant factor in explaining flood control in the study area. Again, the Pseudo R2 (0.62) as revealed in Table 2 indicates that $62 \%$ of total variation in flood control in the study area can be explained by road network, drainage system, planned environment and public awareness.

Classified + if predicted $\operatorname{Pr}(\mathrm{D})>=.5$

Table-5. Classification table.

True D defined as FLC != O

\begin{tabular}{|c|c|c|}
\hline Classified & \multicolumn{2}{|c|}{ Average marginal effects } \\
\hline Sensitivity & $\operatorname{Pr}(+\mathrm{I} \quad \mathrm{D})$ & $7.54 \%$ \\
\hline Specificity & $\operatorname{Pr}(-\mathrm{I} \quad \sim \mathrm{D})$ & $98.88 \%$ \\
\hline Positive predictive value & $\operatorname{Pr}(\mathrm{D} \quad \mathrm{I}$ & $16.94 \%$ \\
\hline Negative predictive value & $\operatorname{Pr}(\sim \mathrm{D} \mathrm{I} \quad-)$ & $65.19 \%$ \\
\hline False + rate for true $\sim D$ & $\operatorname{Pr}(+\mathrm{I} \sim \mathrm{D})$ & $1.12 \%$ \\
\hline False - rate for true D & $\operatorname{Pr}(-\mathrm{I}$ & $100.00 \%$ \\
\hline False + rate for classified + & $\operatorname{Pr}(\sim \mathrm{D} \mathrm{I}$ & $100.00 \%$ \\
\hline False - rate for classified - & $\operatorname{Pr}\left(\begin{array}{lll}D & \mathrm{I} & -\end{array}\right)$ & $34.81 \%$ \\
\hline Correctly classified & & $64.71 \%$ \\
\hline
\end{tabular}

The study area is a flat terrain that encourages water lodging. The stagnancy causes environmental pollution. The community lacks layout plans and is characterized by uncontrolled growth. Minimum setbacks are not observed. Due to its location as a nodal town, the study area is attracting migration of people from different part of the country for commercial activities and trans border trade. Increase in population without adequate planning thus causes uneven development. The seasonal floods caused displacement of people and negative impact on available infrastructure and health status of inhabitants.

The implication of these findings is that road network system; efficient drainage system; effective planned environment and public awareness among the residents are key factors to ensure good flood control in Owode town of Ogun State. Thus, this study serves as a clarion call to all important stakeholders in environmental management to provide adequate and timely attention to these essential factors of flood control and management in the study area. This study finding are consistent with Hula and Udoh [26]; Abolade, et al. [25]; Hula and Udoh [26] and Ali and Sulaiman [10]. More importantly, the study empirical results underline the relative importance of the theoretical background (Integrated Non-Structural Model - ISM) of the study.

\section{Conclusion and Recommendations}

The results point out the significance of good road network, better drainage system, planned environment, and public awareness as land use planning measures is aiming to stop flood occurrences in Owode town. Thus, an integration of these measures can sustainably reduce flood risk in flood prone towns or cities like Owode.

In line with the above, this study recommends that: 
i. There is need to upgrade the current road network in the study area due to increase in number of vehicular in relation to border commercial activities.

ii. Effective and efficient drainage system that can accommodate excessive rainfall are highly required in the town.

iii. Government needs to re-evaluate planned environmental policies that will control both human activities and natural habitats.

iv. There should be more concerted efforts on educating the public on the use of environment and possible hazards of non-compliance with flood control measures.

\section{References}

[1] A. A. Bokhari, G. D. Hu, H. Al-Mokredi, and S. Monsour, "Land use planning," Asian Journal of Information Technology, vol. 9, pp. 164-169, 2010.

[2] D. Thomas, "The importance of development Plans/Land use policy for development control," Prepared for the USAID/OAS PostGeorges Disaster Mitigation Project, Workshop for Building Inspectors, January, 15 - 26, 2001.

[3] U. Habitat, "Increasing synergy for greater national ownership," UN-Habitat Global Activities Report. Retrieved from: www.unhabitat.org/gc25documents2015.

[4] D. Svetlana, D. Radovan, and D. Ján, "The economic impact of floods and their importance in different regions of the world with emphasis on Europe," Procedia Economics and Finance, vol. 34, pp. 649-655, 2015.Available at: https://doi.org/10.1016/s2212$5671(15) 01681-0$.

[5] M. Ajibola, E. Izunwanne, and A. Ogungbemi, "Assessing the effects of flooding on residential property values In Lekki Phase I, Lagos, Nigeria," International Journal of Asian Social Science, vol. 2, pp. $271-282,2012$.

[6] M. Spaliviero, M. Dapper, and M. D. S., "Flood analysis of the Limpopo River basin through past evolution reconstruction and a geomorphological approach," Natural Hazards and Earth System Sciences, vol. 14, pp. 2027-2039, 2014.

[7] M. Adetunji and O. Oyeleye, "Evaluation of the causes and effects of flood in Apete, Ido local government area, Oyo State, Nigeria," Evaluation, vol. 3, pp. 19-26, 2013.

[8] J. Lamond, N. Bhattacharya, and R. Bloch, "The role of solid waste management as a response to urban flood risk in developing countries, a case study analysis," WIT Transactions on Ecology and the Environment, vol. 159, pp. 193-204, 2012.

[9] N. S. Rao, T. J. B. Carruthers, P. Anderson, L. Sivo, T. Saxby, T. Durbin, V. Jungblut, T. Hills, and S. Chape, "An economic analysis of ecosystem-based adaptation and engineering options for climate change adaptation in Lami Town, Republic of the Fiji Islands," A Technical report by the Secretariat of the Pacific Regional Environment Programme. - Apia, Samoa: SPREP, 2013.

[10] M. H. Ali and M. S. Sulaiman, The causes and consequences of the informal settlements in Zanzibar Shaping the Change, Informal Settlements: Policy. Germany: Land Use and Tenure, XXIII FIG Congress Munich, 2006.

[11] C. Nwigwe and T. Emberga, "An Assessment of causes and effects of flood in Nigeria," Standard Scientific Research and Essays, vol. 2, pp. 307-315, 2014.

[12] A. L. Katchova, Agricultural contracting and agrifood competition. Book Chapter in the Ethics and Economics of Agrifood Competition, Harvey S. James. Springer, 2013.

[13] J. Kwari, S. Ayuba, and L. Denis, "Cross case assessment of the impacts of flooding on socio-economic development and agriculture in Kogi state," International Journal, vol. 3, pp. 146-155, 2015.

[14] K. Pauw and J. Thurlow, "Economic losses and poverty effects of drought and floods in Malawi, International Flood Policy Research Institute, Malawi Strategy Support Program Policy, Brief No. 2," pp. 1-4, 2009.

[15] O. Ebuzoeme, "Evaluating the effects of flooding in six communities in Awka Anambra State of Nigeria," Journal of Environment and Earth Science, vol. 5, pp. 26-38, 2015.

[16] A. Gharagozlou, H. Nazari, and M. Seddighi, "Spatial analysis for food control by using environmental modeling," Journal of Geographic Information System, vol. 3, pp. 367-372, 2011 .Available at: https://doi.org/10.4236/jgis.2011.34035.

[17] A. K. Etuonovbe, The devastating effect of flooding in Nigeria: Hydrography and the environment. TSO6J, Epworth. Zimbabwe: FIG Working Week, 2011

[18] S. U. Onwuka, F. O. Ikekpeazu, and D. C. Onuoha, " Assessment of the causes Of 2012 floods In Aguleri and Umuleri, Anambra East local government area of Anambra State, Nigeria," British Journal of Environmental Sciences, vol. 3, pp. 43-57, 2015.

[19] A. Shah, H. Khan, and E. Qazi, "Damage assessment of flood affected mud houses in Pakistan," Journal of Himalayan Earth Sciences, vol. 46, pp. 99-110, 2013.

[20] S. Doocy, A. Daniels, S. Murray, and T. D. Kirsch, "The human impact of floods: A hstorical review of events 1980-2009 and systematic literature review," PLOS Currents Disasters, vol. 1, pp. 1-27, 2013.Available at: 10.1371/currents.dis.f4deb457904936bo7co9daa98ee8171a.
T. H. Dewan, "Societal impacts and vulnerability to floods in Bangladesh and Nepal," Weather and Climate Extremes, vol. 7, pp. 36-

[21] T. H. Dewan, "Societal impacts and vulnerability to floods in Bangladesh and Nepal," Weather and Climate Extremes, vol. 7, pp. 36-
42, 2015.Available at: https://doi.org/10.1016/j.wace.2014.11.001.

[22] J. S. Long, Regression models for nominal and ordinal outcomes. Indiana: Sage, 2012.

[23] N. Alfasi, J. Almagor, and I. Benenson, "The actual impact of comprehensive land-use plans: Insights from high resolution observations," Land Use Policy, vol. 29, pp. 862-877, 2012.Available at: https://doi.org/10.1016/j.landusepol.2012.01.003.

[24] R. C. Hill, W. E. Griffiths, and G. C. Lim, Principles of econometrics. United States of America: John Wiley and Sons, Inc, 2008.

[25] O. Abolade, A. B. Muili, and S. A. Ikotun, "Impacts of flood disaster in Agege local government area Lagos, Nigeria," International Journal of Development and Sustainability, vol. 2, pp. 2354-2367, 2013.

[26] M. Hula and J. Udoh, "An assessment of the impact of flood events in Makurdi, Nigeria," Civil and Environmental Research, vol. 7, pp. 53-60, 2015.

[27] U. Nkwunonwo, M. Whitworth, and B. Baily, "A review and critical analysis of the efforts towards urban flood risk management in the Lagos region of Nigeria," Natural Hazards and Earth System Sciences, vol. 16, pp. 349-369, 2016.Available at: https://doi.org/10.5194/nhess-16-349-2016.

[28] M. Miguez, A. Veról, M. de Sousa, and O. Rezende, "Urban floods in lowlands-levee systems, unplanned urban growth and river restoration alternative: A case study in Brazil," Sustainability, vol. 7, pp. 11068-11097, 2015.Available at: https://doi.org/10.3390/su70811068.

[29] D. Sanderson, "Cities, disasters and livelihoods," Environment and Urbanization, vol. 12, pp. 93-102, 2000.

[30] W. Ligtvoet, H. Hilderink, A. Bouwman, P. V. Puijenbroek, P. Lucas, and M. Witmer, "Towards a world of cities in $2050-$ an outlook on water-related challenges," Background Report to the UN-Habitat Global Report, The Hague: PBL Netherlands Environmental Assessment Agency2014.

[31] P. Luo, B. He, K. Takara, Y. E. Xiong, D. Nover, W. Duan, and K. Fukushi, "Historical assessment of Chinese and Japanese flood management policies and implications for managing future floods," Environmental Science Eं Policy, vol. 48, pp. 265-277, 2015.Available at: https://doi.org/10.1016/j.envsci.2014.12.015.

[32] I. Adelekan, "Flood risk management by public and private agents in the coastal city of Lagos," presented at the 6th International Conference on flood Management, September 2014, Sao Paulo- Brazil, 2014.

[33] Z. Tang, C. M. Hussey, and T. Wei, "Assessing local land use planning's awareness, analysis, and actions for climate change," International Journal of Climate Change Strategies and Management, vol. 1, pp. 368-38 1, 2009.

[34] W. S. Nchito, "Flood risk in unplanned settlements in Lusaka," Environment and Urbanization, vol. 19, pp. 539-551, 2007.Available at: https://doi.org/10.1177/0956247807082835.

[35] F. N. Correia, M. Fordham, M. da GRAča Saraiva, and F. Bernardo, "Flood hazard assessment and management: interface with the public," Water Resources Management, vol. 12, pp. 209-227, 1998. 
[36] S. Idris and L. M. Dharmasiri, "Flood risk inevitability and flood risk management in urban areas: A review," Journal of geography and Regional Planning, vol. 8, pp. 205-209, 2015.Available at: https://doi.org/10.5897/jgrp2015.0510.

[37] R. W. Smith and V. Bugni, "Symbolic interaction theory and architecture," Symbolic Interaction, vol. 29, pp. 14-18, 2006.

[38] R. V. Krejcie and D. W. Morgan, "Determining sample size for research activities," Educational and Psychological Measurement, vol. 30, pp. 607-610, 1970.Available at: https://doi.org/10.1177/001316447003000308.

[39] U. Sekaran, Research methods for business: A skill-building approach, 4th ed. Hoboken: John, Wiley\& Sons, Inc, 2003.

[40] G. D. Garson, "Ordinal regression. In state notes: Topics in multivariate analysis." Retrieved from: http://faculty.chass.ncsu.edu/garson/pa765/statnote.htm. [Accessed 22.11.2019], 2011.

[41] D. O. V. Uche, "The environmental effects of flood disaster in Anambra state," Pelagia Resserch Library Advances in Applied Science Research, vol. 4, pp. 499-505, 2013.Available at: https://doi.org/10.15242/ijaaee.c0417030. 